Article

\title{
Bioactive 30-Noroleanane Triterpenes from the Pericarps of Akebia trifoliata
}

\author{
Jing Wang ${ }^{1,2,3}$, Qiao-Lin Xu ${ }^{2}$, Meng-Fei Zheng ${ }^{1,3}$, Hui Ren ${ }^{1,3}$, Ting Lei ${ }^{1,3}$, Ping Wu ${ }^{1}$, \\ Zhong-Yu Zhou ${ }^{1}$, Xiao-Yi Wei ${ }^{1}$ and Jian-Wen Tan ${ }^{1, *}$ \\ 1 Key Laboratory of Plant Resources Conservation and Sustainable Utilization, \\ South China Botanical Garden, Chinese Academy of Sciences, Guangzhou 510650, China \\ 2 Biotechnology Division, Guangdong Academy of Forestry, Guangzhou 510520, China \\ 3 College of Life Sciences, University of Chinese Academy of Sciences, Beijing 100049, China \\ * Author to whom correspondence should be addressed; E-Mail: jwtan@scbg.ac.cn; \\ Tel./Fax: +86-20-3708-2054.
}

Received: 20 February 2014; in revised form: 27 March 2014 / Accepted: 28 March 2014 /

Published: 4 April 2014

\begin{abstract}
Two new 30-noroleanane triterpenes, $2 \alpha, 3 \beta, 20 \alpha$-trihydroxy-30-norolean-12-en28-oic acid (1), $2 \alpha, 3 \beta$-dihydroxy-23-oxo-30-norolean-12,20(29)-dien-28-oic acid (2), were isolated from the pericarps of Akebia trifoliata, together with four known ones, $3 \beta$-akebonoic acid (3), 2 $\alpha, 3 \beta$-dihydroxy-30-noroleana-12,20(29)-dien-28-oic acid (4), $3 \alpha$-akebonoic acid (5) and quinatic acid (6). Their structures were established on the basis of detailed spectroscopic analysis, and they were all isolated from the pericarps of A. trifoliata for the first time. Compounds 3-6 showed in vitro bacteriostatic activity against four assayed Gram-positive bacterial strains. In particular 3 showed antibacterial activity toward MRSA with a MIC value $25 \mu \mathrm{g} / \mathrm{mL}$, which was more potent than kanamycin (MIC $125 \mu \mathrm{g} / \mathrm{mL}$ ). No compounds showed antibacterial activity toward the three Gram-negative bacteria tested. Compounds $\mathbf{4}$ and $\mathbf{5}$ showed interesting in vitro growth inhibitory activity against human tumor $\mathrm{A} 549$ and $\mathrm{HeLa}$ cell lines, with $\mathrm{IC}_{50}$ values ranging from 8.8 and $5.6 \mu \mathrm{M}$, respectively. Compounds 1, 2, 5 and $\mathbf{6}$ were further revealed to show significant in vitro $\alpha$-glucosidase inhibitory activity with $\mathrm{IC}_{50}$ values from 0.035 to $0.367 \mathrm{mM}$, which were more potent than the reference compound acarbose $\left(\mathrm{IC}_{50} 0.409 \mathrm{mM}\right)$.
\end{abstract}

Keywords: Akebia trifoliata; nortriterpenoids; bacteriostatic activity; cytotoxicity; $\alpha$-glucosidase inhibitor 


\section{Introduction}

Akebia trifoliata (Thunb.) Koidz., belonging to the family Lardizabalaceae, is a perennial, woody liana mainly distributed in the eastern part of Asia [1]. The fruit of A. trifoliata, commonly called 'Bayuezha' in China, has long been consumed by the local people as a delicious food [2]. The air-dried stems and fruits of $A$. trifoliata have also traditionally been used in China as an antiphlogistic, antineoplastic and diuretic agent for hundreds of years [3,4]. Previously, phytochemical studies have revealed many triterpenes and triterpene saponins from A. trifoliata [5-7], and phenolics and lignans were also reported from this species [8,9]. However, those studies were mainly concentrated on the stems and seldom focused on the pericarps, although it is highly possible that the pericarps of $A$. trifoliata would be a promising source of functional bioactive natural products [10-12]. Very recently, a phytochemical study revealed fifteen compounds, including eleven noroleanane triterpenoids from a methanol extract of pericarps of A. trifoliata [13], suggesting noroleanane triterpenoids to be characteristic in the pericarps of this species. Noroleanane triterpenoids are a group of novel natural products bearing skeletons with one or two carbons missing from the basic oleanane skeleton, which are so far only discovered in a small group of plants and some of them have been revealed to show significant bioactivities [14]. With the aim of clarifying the uncharacterized bioactive compounds in the pericarps of $A$. trifoliata, a phytochemical study on the pericarps of this species was carried out, whereby two new (compounds 1-2) and four known 30-noroleanane triterpenes (compounds 3-6) were obtained (Figure 1). Herein reported are the isolation and structure elucidation of these compounds, as well as their bacteriostatic, cytotoxic and $\alpha$-glucosidase inhibitory activities.

Figure 1. Chemical structures of compounds 1-6.
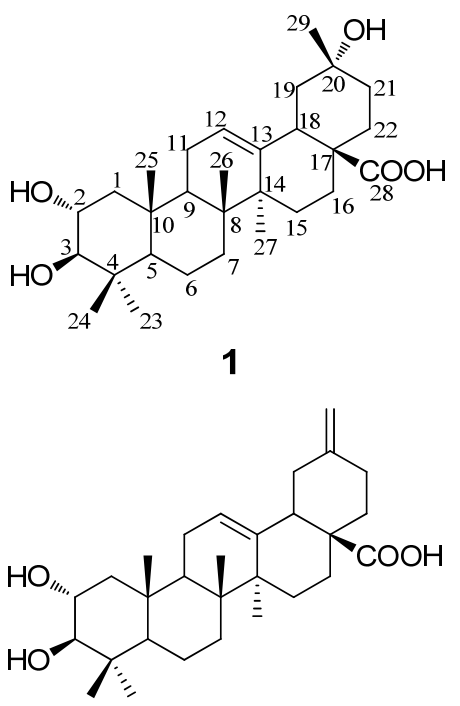

4

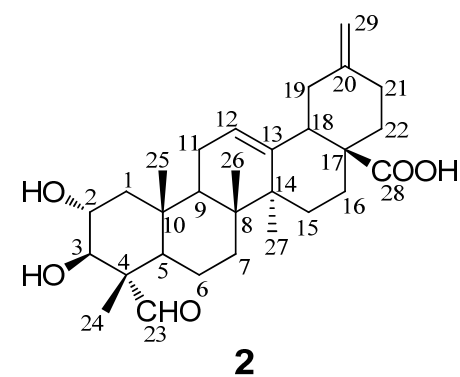

2

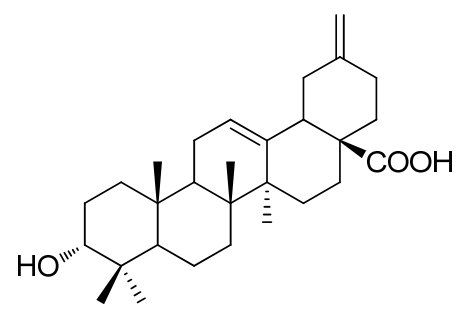

5<smiles>C=C1CCC2C3=CCC4C(C)(CCC5C(C)(C)C(O)CCC54C)C3CCC2(C(=O)O)C1</smiles>

3

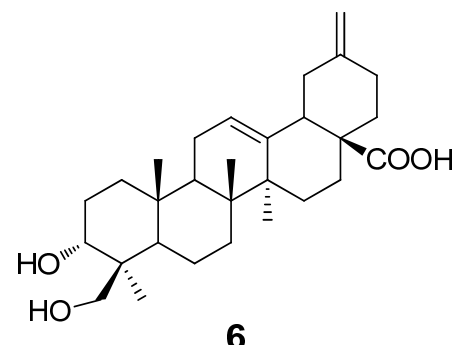

\section{Results and Discussion}

Compound 1 was obtained as a white, amorphous powder. Positive mode HRESIMS indicated a molecular formula of $\mathrm{C}_{29} \mathrm{H}_{46} \mathrm{O}_{5}\left([\mathrm{M}+\mathrm{Na}]^{+} \mathrm{m} / z\right.$ 497.3235, calcd. 497.3237), implying seven degrees of unsaturation. The ${ }^{1} \mathrm{H}-\mathrm{NMR}$ spectrum of $\mathbf{1}$ (Table 1) showed signals readily recognized for six tertiary 
methyl groups at $\delta 1.32(3 \mathrm{H}, \mathrm{Me}-29), 1.06(3 \mathrm{H}, \mathrm{Me}-27), 1.03(3 \mathrm{H}, \mathrm{Me}-23), 0.82(3 \mathrm{H}, \mathrm{Me}-25), 0.81$ $(3 \mathrm{H}, \mathrm{Me}-24)$ and $0.76(3 \mathrm{H}, \mathrm{Me}-26)$. In addition, proton signals for two oxymethines at $\delta 3.77(1 \mathrm{H}, \mathrm{H}-2)$ and $3.09(1 \mathrm{H}, \mathrm{H}-3)$, and an olefinic proton at $\delta 5.26(1 \mathrm{H}, \mathrm{H}-12)$ were also observed. The ${ }^{13} \mathrm{C}-\mathrm{NMR}$ and DEPT spectra (Table 1) of 1 supported the above analysis, which showed 29 carbons including six methyls $\left(\delta_{\mathrm{C}} 29.2,17.6,16.7,17.4,25.9\right.$ and 25.6), nine methylenes, six methines [including one olefinic methine at $\delta 122.5(\mathrm{C}-12)$, two oxy-methines at $\delta 68.5(\mathrm{C}-2)$ and 83.7 (C-3)], and eight quaternary carbons [including an olefinic quaternary carbon at $\delta 144.3$ (C-13), a carboxyl carbon at $\delta$ 179.9 (C-28), and an oxy-quaternary carbon at $\delta 69.8$ (C-20)]. These above findings accounted for two of the seven degrees of unsaturation, suggesting that $\mathbf{1}$ is a pentacyclic nortriterpenoid. Comparison of the NMR data of 1 with those of maslinic acid indicated that they were structurally closely related, with the major difference of a germinal methyl group attached at C-20 in maslinic acid being replaced by a hydroxyl group in $\mathbf{1}$ [15]. This assignment was consistent with the molecular formula of $\mathbf{1}$ and in accord with the significant change of the chemical shift value for C-20 from $\delta_{\mathrm{C}} 30.8$ in maslinic acid to $\delta_{\mathrm{C}} 69.7 \mathrm{in} 1$. The location of the hydroxyl group at C-20 was furhter supported by HMBC correlations from $\delta_{\mathrm{H}} 1.32\left(\mathrm{H}_{3}-29\right)$ to $\delta_{\mathrm{C}} 47.6(\mathrm{C}-19), 69.8(\mathrm{C}-20), 36.1(\mathrm{C}-21)$ and from $\delta_{\mathrm{H}} 1.75\left(\mathrm{H}_{2}-22\right)$ to $\mathrm{C}-20 . \mathrm{In}$ the NOESY spectrum, the important NOE correlation between Me-29 $\left(\delta_{\mathrm{H}} 1.32\right)$ and $\mathrm{H}-18\left(\delta_{\mathrm{H}} 2.98\right)$ was observed, which supported the hydroxyl group at C-20 was $\alpha$-orientation (Figure 2). In addition, the HMBC correlations (Figure 3$)$ from $\delta_{\mathrm{H}} 1.75(\mathrm{H}-22)$ and $2.98(\mathrm{H}-18)$ to $\delta_{\mathrm{C}} 179.9(\mathrm{C}-28)$ supported the location of the carboxyl group at $\mathrm{C}-17$. The $\mathrm{HMBC}$ correlations from $\delta_{\mathrm{H}} 5.26(\mathrm{H}-12)$ to $\delta_{\mathrm{C}} 42.1$ (C-14), 44.3 (C-18) and 47.9 (C-9) supported the location of double bond at C-12(13). The HMBC correlations from $\delta_{\mathrm{H}} 3.77(\mathrm{H}-2)$ to $\delta_{\mathrm{C}} 47.7(\mathrm{C}-1)$ and $\delta_{\mathrm{C}} 83.7(\mathrm{C}-3)$, and from $\delta_{\mathrm{H}} 3.09(\mathrm{H}-3)$ to $\delta_{\mathrm{C}} 47.7$ (C-1), 68.5 (C-2), 39.7 (C-4), 29.2 (C-23) and 17.6 (C-24) supported that each of C-2 and C-3 was attached with a hydroxyl group.

Table 1. ${ }^{1} \mathrm{H}-\mathrm{NMR}$ and ${ }^{13} \mathrm{C}-\mathrm{NMR}$ data for compounds $\mathbf{1}$ and $\mathbf{2}, \delta$ in ppm and $J$ in $\mathrm{Hz}$.

\begin{tabular}{ccccc}
\hline No. & $\boldsymbol{\delta}_{\mathbf{C}}(\mathbf{1})$ & $\boldsymbol{\delta}_{\mathbf{H}}(\mathbf{1})$ & $\boldsymbol{\delta}_{\mathbf{C}}(\mathbf{2})$ & $\boldsymbol{\delta}_{\mathbf{H}}(\mathbf{2})$ \\
\hline 1 & $47.7 \mathrm{CH}_{2}$ & $1.95(\mathrm{dd}, 11.8,3.7), 0.97(\mathrm{~m})$ & $47.8 \mathrm{CH}_{2}$ & $2.29(\mathrm{dd}, 12.0,4.2), 1.41(\mathrm{~m})$ \\
2 & $68.5 \mathrm{CH}$ & $3.77(\mathrm{td}, 11.8,9.5,3.7)$ & $67.9 \mathrm{CH}$ & $4.24(\mathrm{td}, 12.0,9.3,4.2)$ \\
3 & $83.7 \mathrm{CH}$ & $3.09(\mathrm{~d}, 9.5)$ & $77.0 \mathrm{CH}$ & $4.06(\mathrm{~d}, 9.3)$ \\
4 & $39.7 \mathrm{C}$ & - & $56.5 \mathrm{C}$ & - \\
5 & $55.8 \mathrm{CH}$ & $0.77(\mathrm{~m})$ & $47.9 \mathrm{CH}$ & $1.64(\mathrm{dd}, 10.5,1.8)$ \\
6 & $18.7 \mathrm{CH}_{2}$ & $1.41(\mathrm{~m}), 1.23(\mathrm{~m})$ & $20.5 \mathrm{CH}_{2}$ & $1.50(\mathrm{~m}), 1.10(\mathrm{~m})$ \\
7 & $33.1 \mathrm{CH}_{2}$ & $1.34(\mathrm{~m}), 1.13(\mathrm{~m})$ & $32.3 \mathrm{CH}_{2}$ & $1.51(\mathrm{~m}), 1.21(\mathrm{~m})$ \\
8 & $39.7 \mathrm{C}$ & - & $39.7 \mathrm{C}$ & - \\
9 & $47.9 \mathrm{CH}$ & $1.53(\mathrm{~m})$ & $47.8 \mathrm{CH}$ & $1.89(\mathrm{~m})$ \\
10 & $38.4 \mathrm{C}$ & - & $38.2 \mathrm{C}$ & - \\
11 & $23.8 \mathrm{CH}_{2}$ & $2.03(\mathrm{~m}), 1.75(\mathrm{~m})$ & $23.6 \mathrm{CH}_{2}$ & $2.07(\mathrm{~d}, 11.1), 1.97(\mathrm{dd}, 11,1,3.4)$ \\
12 & $122.5 \mathrm{CH}$ & $5.26(\mathrm{t}, 3.2)$ & $122.5 \mathrm{CH}$ & $5.48(\mathrm{t}, 3.4)$ \\
13 & $144.3 \mathrm{C}$ & - & $144.1 \mathrm{C}$ & - \\
14 & $42.1 \mathrm{C}$ & - & $42.0 \mathrm{C}$ & - \\
15 & $28.2 \mathrm{CH}_{2}$ & $1.86(\mathrm{~m}), 0.98(\mathrm{~m})$ & $28.1 \mathrm{CH}_{2}$ & $2.17(\mathrm{~m}), 1.99(\mathrm{~m})$ \\
16 & $23.7 \mathrm{CH}_{2}$ & $2.03(\mathrm{~m}), 1.76(\mathrm{~m})$ & $23.7 \mathrm{CH}_{2}$ & $2.18(\mathrm{~m}), 1.93(\mathrm{~m})$ \\
17 & $46.6 \mathrm{C}$ & - & $46.9 \mathrm{C}$ & - \\
18 & $44.3 \mathrm{CH}$ & $2.98(\mathrm{dd}, 14.0,3.7)$ & $47.4 \mathrm{CH}$ & $3.23(\mathrm{dd}, 13.5,4.6)$ \\
\hline
\end{tabular}


Table 1. Cont.

\begin{tabular}{ccccc}
\hline No. & $\boldsymbol{\delta}_{\mathbf{C}}(\mathbf{1})$ & $\boldsymbol{\delta}_{\mathbf{H}}(\mathbf{1})$ & $\boldsymbol{\delta}_{\mathbf{C}}(\mathbf{2})$ & $\boldsymbol{\delta}_{\mathbf{H}}(\mathbf{2})$ \\
\hline 19 & $47.6 \mathrm{CH}_{2}$ & $2.10(\mathrm{bt}, 14.0), 1.57(\mathrm{~m})$ & $41.8 \mathrm{CH}_{2}$ & $2.64(\mathrm{bt}, 13.5), 2.25(\mathrm{~m})$ \\
20 & $69.8 \mathrm{C}$ & - & $148.9 \mathrm{C}$ & - \\
21 & $36.1 \mathrm{CH}_{2}$ & $1.73(\mathrm{~m}), 1.57(\mathrm{~m})$ & $30.2 \mathrm{CH}_{2}$ & $2.30(\mathrm{~m}), 2.20(\mathrm{~m})$ \\
22 & $35.0 \mathrm{CH}_{2}$ & $1.75(\mathrm{~m}$, overlap) & $38.3 \mathrm{CH}_{2}$ & $2.13(\mathrm{~m}), 1.93(\mathrm{~m})$ \\
23 & $29.2 \mathrm{CH}_{3}$ & $1.03(\mathrm{~s})$ & $206.3 \mathrm{CH}$ & $9.67(\mathrm{~s})$ \\
24 & $17.6 \mathrm{CH}_{3}$ & $0.81(\mathrm{~s})$ & $10.6 \mathrm{CH}_{3}$ & $1.43(\mathrm{~s})$ \\
25 & $16.7 \mathrm{CH}_{3}$ & $0.82(\mathrm{~s})$ & $16.9 \mathrm{CH}_{3}$ & $1.00(\mathrm{~s})$ \\
26 & $17.4 \mathrm{CH}_{3}$ & $0.76(\mathrm{~s})$ & $17.2 \mathrm{CH}_{3}$ & $0.96(\mathrm{~s})$ \\
27 & $25.9 \mathrm{CH}_{3}$ & $1.06(\mathrm{~s})$ & $26.0 \mathrm{CH}_{3}$ & $1.23(\mathrm{~s})$ \\
28 & $179.9 \mathrm{C}$ & - & $179.4 \mathrm{C}$ & - \\
29 & $25.6 \mathrm{CH}_{3}$ & $1.32(\mathrm{~s})$ & $107.0 \mathrm{CH}_{2}$ & $4.77(\mathrm{~s}), 4.81(\mathrm{~s})$ \\
\hline
\end{tabular}

Recorded in pydine- $d_{5}$ at $600 \mathrm{MHz}$ for ${ }^{1} \mathrm{H}-\mathrm{NMR}, 150 \mathrm{MHz}$ for ${ }^{13} \mathrm{C}$-NMR.

Figure 2. Important NOESY correlations of compounds $\mathbf{1}$ and $\mathbf{2}$.
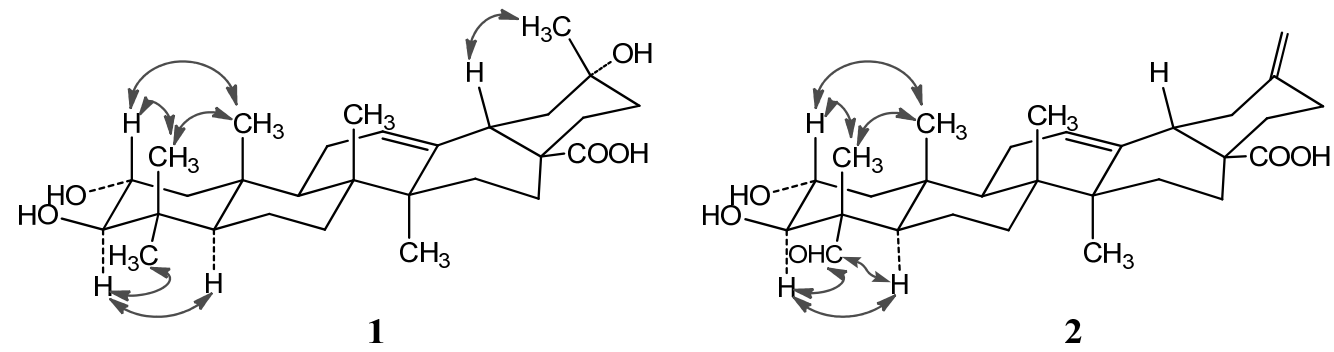

Figure 3. Selected HMBC correlations of compounds 1 and 2.

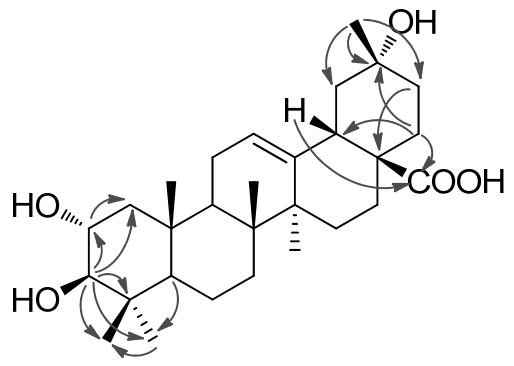

1

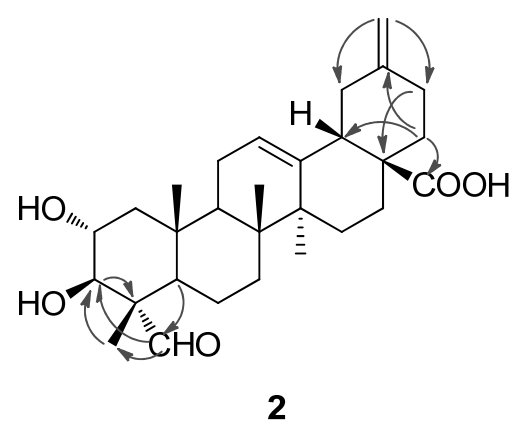

The NOE correlations of H-2 with Me-24 ( $\left.\delta_{\mathrm{H}} 0.81\right)$ and Me-25 ( $\left.\delta_{\mathrm{H}} 0.82\right)$, and the large proton spin-coupling constant of $\mathrm{H}-3\left({ }^{3} J_{\mathrm{H}-2, \mathrm{H}-3}=9.5 \mathrm{~Hz}\right)$ further supported that the hydroxyl groups at C-2 and C-3 were $\alpha$ - and $\beta$-orientation, respectively [5]. Therefore, 1 was unambiguously identified as $2 \alpha, 3 \beta, 20 \alpha$-trihydroxy-30-norolean-12-en-28-oic acid.

Compound 2 was obtained as a white amorphous powder with molecular formula $\mathrm{C}_{29} \mathrm{H}_{42} \mathrm{O}_{5}$ as determined by HRESIMS. The ${ }^{1} \mathrm{H}$ - and ${ }^{13} \mathrm{C}-\mathrm{NMR}$ data (see Table 1 ) suggested that $\mathbf{2}$ is also a pentacyclic nortriterpenoid. Careful analysis of the ${ }^{1} \mathrm{H}$ - and ${ }^{13} \mathrm{C}-\mathrm{NMR}$ spectra indicated that 2 closely resembled 2 $\alpha, 3 \beta$-dihydroxy-30-noroleana-12,20(29)-dien-28-oic acid [5], a literature reported noroleanane triterpenoid which was also obtained in this study as compound 4. Except that the 
resonances for the methyl group at C-23 in 4 were replaced by signals $\left[\delta_{\mathrm{H}} 9.67(1 \mathrm{H}, \mathrm{s}, \mathrm{H}-23) ; \delta_{\mathrm{C}} 206.3\right.$ (C-23)] for an aldehyde group in $\mathbf{2}$. These findings led to establish the structure of $\mathbf{2}$ as shown in Figure 1, which was well supported by the $2 \mathrm{D}$ NMR data. In the HMBC spectrum, the ${ }^{1} \mathrm{H}-{ }^{13} \mathrm{C}$ long-range correlations from $\delta_{\mathrm{H}} 9.67(1 \mathrm{H}, \mathrm{H}-23)$ to $\delta_{\mathrm{C}} 10.6(\mathrm{C}-24)$, and from $\delta_{\mathrm{H}} 4.06(1 \mathrm{H}, \mathrm{H}-3)$ to $\delta_{\mathrm{C}}$ 206.3 (C-23) and 10.6 (C-24) were observed, which confirmed the attachment of the aldehyde group at C-4 (Figure 3). The HMBC correlations from $\delta_{\mathrm{H}} 4.24(1 \mathrm{H}, \mathrm{H}-2)$ to $\delta_{\mathrm{C}} 76.9(\mathrm{C}-3)$, and from $\delta_{\mathrm{H}} 4.06$ $(1 \mathrm{H}, \mathrm{H}-3)$ to $\delta_{\mathrm{C}} 67.9(\mathrm{C}-2), 56.5(\mathrm{C}-4), 206.3(\mathrm{C}-23)$ and $10.6(\mathrm{C}-24)$, and the large proton spin-coupling constant of $\mathrm{H}-3\left({ }^{3} J_{\mathrm{H}-2, \mathrm{H}-3}=9.3 \mathrm{~Hz}\right)$ supported the $\beta$ - and $\alpha$-orientation of the hydroxyls at C-3 and C-2, respectively [5]. The HMBC correlations from $\mathrm{H}_{2}-29\left(\delta_{\mathrm{H}} 4.81,4.77\right)$ to $\mathrm{C}-19\left(\delta_{\mathrm{C}} 41.8\right)$ and $\mathrm{C}-21$ $\left(\delta_{\mathrm{C}} 30.2\right)$ confirmed the exocyclic double bond at C-20(29). The $\alpha$-orientation of the aldehyde group at C-4 was evidenced by significant NOE correlations in the NOESY spectrum of H-23 $\left(\delta_{\mathrm{H}} 9.67\right)$ with H-3 $\left(\delta_{\mathrm{H}} 4.06\right)$ and $\mathrm{H}-5\left(\delta_{\mathrm{H}} 1.64\right)$, and of $\mathrm{H}-2$ with $\mathrm{H}_{3}-24\left(\delta_{\mathrm{H}} 1.43\right)$ and $\mathrm{H}_{3}-25\left(\delta_{\mathrm{H}} 1.00\right)$ (Figure 2$)$. Therefore, compound 2 was determined as $2 \alpha, 3 \beta$-dihydroxy-23-oxo-30-norolean-12,20(29)-dien-28-oic acid.

The four known compounds were identified as $3 \beta$-akebonoic acid (3) [16], 2 $\alpha, 3 \beta$-dihydroxy-30noroleana-12,20(29)-dien-28-oic acid (4) [5], 3 $\alpha$-akebonoic acid (5) [16] and quinatic acid (6) [17] by comparison of their spectral data $\left({ }^{1} \mathrm{H}\right.$ and ${ }^{13} \mathrm{C}-\mathrm{NMR}$ and MS) to those reported in the literature. They were all reported here from the pericarps of $A$. trifoliata for the first time.

The in vitro antibacterial activity of the six isolated compounds against four Gram-positive bacteria [St. aureus (CMCC26003), B. cereus (CMCC63302), B. subtilis (CMCC63501) and MRSA] and three Gram-negative bacteria [E. coli (CMCC44102), Sa. typhimurium (CMCC44102) and Sh. dysenteriae (CMCC51252)] were evaluated using a microdilution titre assay as described in the Experimental section. As shown in Table 2, compound $\mathbf{3}$ displayed the best in vitro bacteriostatic activity against all the Gram positive bacteria assayed with MICs from 12.5 to $25 \mu \mathrm{g} / \mathrm{mL}$. Compounds $\mathbf{4 , 5}$ and $\mathbf{6}$ showed bacteriostatic activity against B. cereus CMCC63302 and B. subtilis CMCC63501 with MICs of 50 and 25 , of 25 and 50 , and of 50 and $12.5 \mu \mathrm{g} / \mathrm{mL}$, respectively. Neither compound showed antibacterial activity toward the three assayed Gram-negative bacteria strains (MICs $>200 \mu \mathrm{g} / \mathrm{mL}$ ). It is noteworthy that compound 3 showed bacteriostatic activity against $M R S A$ with MIC $25 \mu \mathrm{g} / \mathrm{mL}$, which was much stronger than reference compound of Kanamycin sulfate (MIC $125 \mu \mathrm{g} / \mathrm{mL}$ ). MRSA, firstly reported as a methicillin-resistant Staphylococcus aureus in the U.K. in 1961, is now a multidrug-resistant strain responsible for a rapidly increasing number of serious infectious diseases throughout the world, which is lacking of effective antimicrobial agents for the control and therapy for its infection.

Table 2. MIC values of compounds $\mathbf{1}-\mathbf{6}$ in $\mu \mathrm{g} / \mathrm{mL}$ against seven bacterial strains.

\begin{tabular}{ccccccccc}
\hline Bacteria & $\mathbf{1}$ & $\mathbf{2}$ & $\mathbf{3}$ & $\mathbf{4}$ & $\mathbf{5}$ & $\mathbf{6}$ & $\mathbf{K}$ & $\mathbf{C}$ \\
\hline S. aureus $(\mathrm{CMCC} 26003)$ & $>200$ & $>200$ & 25 & 200 & $>200$ & $>200$ & 1.9 & 50 \\
MRSA & $>200$ & $>200$ & 25 & 200 & $>200$ & $>200$ & 125 & $>200$ \\
B. cereus $(\mathrm{CMCC63302)}$ & $>200$ & $>200$ & 25 & 50 & 25 & 50 & 3.9 & 200 \\
B. subtilis $(\mathrm{CMCC63501)}$ & $>200$ & $>200$ & 12.5 & 25 & 50 & 12.5 & 3.9 & 200 \\
E. coli (CMCC44102) & $>200$ & $>200$ & $>200$ & $>200$ & $>200$ & $>200$ & 3.9 & 12.5 \\
S. typhimurium $(\mathrm{CMCC44102)}$ & $>200$ & $>200$ & $>200$ & $>200$ & $>200$ & $>200$ & 3.9 & 12.5 \\
S. dysenteriae (CMCC51252) & $>200$ & $>200$ & $>200$ & $>200$ & $>200$ & $>200$ & 3.9 & 12.5 \\
\hline
\end{tabular}

$\mathrm{K}=$ kanamycin sulfate, $\mathrm{C}=$ cefradine. 
These compounds were also tested for their in vitro cytotoxicity against three human tumor cell lines, A549 (human lung adenocarcinoma), HeLa (human cervical carcinoma) and HepG2 (human liver hepatocellular carcinoma), using the MTT method as described. The resulting $\mathrm{IC}_{50}$ values are displayed in Table 3. Compounds 4 and 5 showed interesting cytotoxicity against A549 and HeLa cell lines, with $\mathrm{IC}_{50}$ values 8.8 and $5.6 \mu \mathrm{M}$, respectively. Compound 3 also showed cytotoxic activity ( $\mathrm{IC}_{50}$ 49.48, 28.63 and $52.89 \mu \mathrm{M}$ ) against the three tested tumor cell lines, but it was weaker than $\mathbf{4}$ and $\mathbf{5}$. New compounds 1-2 and compound 6 did not exhibit cytotoxic activity $\left(\mathrm{IC}_{50}>100 \mu \mathrm{M}\right)$ in this bioassay. It could be deduced that the exocyclic double bond at C-20(29) might be an important active center for this type of nortriterpenoids to "maintain" their potential cytotoxicity, based on comparison of the structures and activities of $\mathbf{1}$ to $\mathbf{4}$. Comparison of the chemical structures of $\mathbf{3}$ and $\mathbf{4}$ versus $\mathbf{5}$ indicated that the $\alpha$-orientation of the hydroxyl group at C-3 could strengthen the cytotoxic activity of this type of nortriterpenoids, while the $\alpha$-hydroxyl group at C-2 seems not necessary. Moreover, a negative effect on the cytotoxicity was evident when Me-23 was oxidized (i.e., replaced by an -CHO group), as supported by analyzing the structure-active relationship of $\mathbf{2}$ and $\mathbf{4}$.

Table 3. Cytotoxicity of compounds $\mathbf{1}-\mathbf{6}\left(\mathrm{IC}_{50}, \mu \mathrm{M}\right)$.

\begin{tabular}{cccc}
\hline Compounds & A549 & HeLa & HepG2 \\
\hline $\mathbf{1}$ & $>100$ & $>100$ & $>100$ \\
$\mathbf{2}$ & $>100$ & $>100$ & $>100$ \\
$\mathbf{3}$ & $49.48 \pm 8.64$ & $28.63 \pm 7.41$ & $52.89 \pm 5.28$ \\
$\mathbf{4}$ & $8.770 \pm 0.59$ & $16.33 \pm 0.12$ & $14.28 \pm 0.49$ \\
$\mathbf{5}$ & $10.59 \pm 0.69$ & $5.61 \pm 0.00$ & $10.39 \pm 1.17$ \\
$\mathbf{6}$ & $>100$ & $>100$ & $>100$ \\
Adriamycin & $0.69 \pm 0.07$ & $0.47 \pm 0.06$ & $1.22 \pm 0.02$ \\
\hline
\end{tabular}

Values represent mean $\pm \mathrm{SD}(\mathrm{n}=3)$ based on three individual experiments.

Compounds 1, 2, 5 and 6 were further tested for their $\alpha$-glucosidase inhibitory activity. The results are listed in Table 4, with acarbose used as a reference compound. Compound $\mathbf{5}$ showed the best $\alpha$-glucosidase inhibitory activity with $\mathrm{IC}_{50}$ value $0.035 \mathrm{mM}$, which was about twelve-fold stronger than acarbose $\left(\mathrm{IC}_{50} 0.409 \mathrm{mM}\right)$. Compound 6 showed significant $\alpha$-glucosidase inhibitory activity with $\mathrm{IC}_{50}$ value $(0.10 \mathrm{mM})$ about four-fold stronger than the reference compound. Though the $\alpha$-glucosidase inhibitory activities of $\mathbf{1}$ and $\mathbf{2}$ ( $\mathrm{IC}_{50} 0.367$ and $0.220 \mathrm{mM}$, respectively) were inferior to $\mathbf{5}$ and $\mathbf{6}$, they were still more potent than acarbose. These results indicated that 30 -noroleanane triterpenes in the pericarps of $A$. trifoliata were effective $\alpha$-glucosidase inhibitors promising to be developed as effective and safe hypoglycemic agents for diabetes chemotherapy [18].

Table 4. $\alpha$-Glucosidase inhibitory activity of compounds 1, 2, 5 and 6 .

\begin{tabular}{cr}
\hline Compounds & $\mathbf{I C}_{\mathbf{5 0}}(\mathbf{m M})$ \\
\hline $\mathbf{1}$ & $0.367 \pm 0.003$ \\
$\mathbf{2}$ & $0.220 \pm 0.004$ \\
$\mathbf{5}$ & $0.035 \pm 0.002$ \\
$\mathbf{6}$ & $0.100 \pm 0.001$ \\
Acarbose & $0.409 \pm 0.006$ \\
\hline
\end{tabular}

Values represent mean $\pm \mathrm{SD}(\mathrm{n}=3)$ based on three individual experiments. 


\section{Experimental}

\subsection{General Information}

Optical rotation were measured on a Perkin-Elmer 341 polarimeter (Perkin- Elmer, Waltham, MA, USA) with $\mathrm{MeOH}$ as solvent at the wavelength of $589 \mathrm{~nm}$ and $20{ }^{\circ} \mathrm{C}$ to gain their specific optical rotation $[\alpha]$ values after calculation. Nuclear magnetic resonance (NMR) spectra were recorded on a Bruker Advance 600 NMR spectrometer (Bruker Biospin corporation, Billerica, MA, USA), Bruker advance 500M NMR spectrometer (Bruker) and a Bruker DRX-400 NMR spectrometer (Bruker Biospin, Rheistetten, Germany) with the solvent residual peaks of $\delta_{\mathrm{H}} 7.22,7.58,8.74$ and $\delta_{\mathrm{C}} 123.4$, $135.4,149.7$ for pyridine- $d_{5}$, and $\delta_{\mathrm{H}} 2.50$ and $\delta_{\mathrm{C}} 39.5$ for DMSO- $d_{6}$. HR-ESI-MS mass spectra were obtained on a Bruker maXis instrument (Bruker Daltonik GmbH, Bremen, Germany) in a positive ion mode after direct injection of the test solutions. ESI-MS data were obtained using a MDS SCIEX API 2000 LC/MS/MS system (Applied Biosystems, Foster City, CA, USA) in both positive and negative ion modes in the range of $m / z$ 50-1000 after the test solutions were directly injected into the ESI source by a syringe pump. Preparative HPLC was carried out on a CXTH P3000 HPLC pump and a UV 3000 UV-Vis Detector with a Fuji-C18 column (10 um-100 A, ChuangXinTongHeng Science And Technology Co., Ltd, Beijing, China); the Performance of MPLC (medium pressure liquid chromatography) is a CXTH P3000 HPLC pump, a UV 3000 UV-Vis Detector and a C18 column $(400 \times 25 \mathrm{mM}$ i.d, $50 \mu \mathrm{M}$, YMC Co. Ltd., Kyoto, Japan).

Column chromatography (CC) was performed with silica gel (80-100 and 200-300 mesh, Qingdao Haiyang Chemical Co., Qingdao, China), YMC ODS-A (50 $\mu \mathrm{m}$, YMC Co. Ltd., Kyoto, Japan), Sephadex LH-20 (Pharmacia Fine Chemical Co. Ltd., Uppsala, Sweden), MCI gel CHP 20P (75-150 $\mu \mathrm{M}$, Mitsubishi Chemical Corp., Tokyo, Japan). Analytical grade petroleum ether (b.p. 60-90 ${ }^{\circ} \mathrm{C}$ ), methanol, ethyl acetate, chloroform, $n$-butanol, acetone were purchased from Tianjin Fuyu Fine Chemical Industry Co. (Tianjin, China); HPLC grade methanol was purchased from J\&K Chemical Ltd. (Beijing, China); Fraction were monitored by precoated HSGF $_{254}$ TLC (Yantai Jiangyou Silica Gel Co. Ltd, Yantai, China), and spot detection was performed under fluorescent light $(\lambda=254 \mathrm{~nm})$, and then spraying $10 \% \mathrm{H}_{2} \mathrm{SO}_{4}$ in ethanol, followed by heating. Kanamycin sulfate, resazurin, pyridine- $d_{5}$, DMSO- $d_{6}, 3-(4,5$-dimethylthiazol-2-yl)-2,5-diphenyltetrazolium bromide (MTT) and $\alpha$-glucosidase were purchased from Sigma Chemical Co. (Sigma-Aldrich, St. Louis, MO, USA). Roswell Park Memorial Institute (RPMI)-1640 medium and fetal calf serum were purchased from Gibco BRL (Gaithersburg, MD, USA). Adriamycin was obtained from Pfizer Italia SRL (Roma, Italy). $p$-Nitrophenyl- $\alpha$-D-glucopyranoside (PNPG) and acarbose were obtained from Tokyo Chemical Industry Co., Ltd. (Tokyo, Japan).

\subsection{Plant Materials}

The pericarps of Akebia trifoliata were collected in September 2009, at Liye of Longshan, Hunan Province, China, identified by Prof. Fu-Wu Xing at South China Botanical Garden, the Chinese Academy of Sciences (CAS). A voucher specimen (No. 20090920) was deposited at the Laboratory of Bioorganic Chemistry of the South China Botanical Garden, Chinese Academy of Sciences. 


\subsection{Extraction and Isolation}

Air-dried pericarps of Akebia trifoliata $(3 \mathrm{~kg})$ were powdered and extracted three times ( 3 days each) with $95 \% \mathrm{EtOH}(9 \mathrm{~L} \times 3)$ at room temperature $\left(25-32{ }^{\circ} \mathrm{C}\right)$. The concentration of the solution under vacuum gave a reddish solid. Then, the resulting residue was suspended in $\mathrm{H}_{2} \mathrm{O}(1.5 \mathrm{~L})$ and successively partitioned with petroleum ether $(1.5 \mathrm{~L} \times 3)$ and ethyl acetate $(1.5 \mathrm{~L} \times 3)$ to afford petroleum ether-soluble $(40.0 \mathrm{~g})$ and EtOAc-soluble $(180 \mathrm{~g})$ fractions after condensation to dryness in vacuo. The petroleum ether-soluble fraction was subjected to silica gel column chromatography $(1000 \times 105 \mathrm{mM}$ i.d. $)$ using a gradient system of petroleum ether-acetone $(100: 0,20: 1,10: 1,5: 1,2: 1$, 1:1, 0:100, $v / v$, each 1.5 L) to give nine fractions $\left(\mathrm{E}_{1}-\mathrm{E}_{9}\right)$ after pooled according to their TLC profiles. $\mathrm{E}_{3}(0.45 \mathrm{~g})$ was repeatedly chromatographied on Sephadex LH-20 column $(1550 \times 13.4 \mathrm{mM}$ i.d. $)$ eluted with acetone to yield compound $5(6.5 \mathrm{mg}) . \mathrm{E}_{4}(1.7 \mathrm{~g})$ was purified on silica gel column chromatography $(1000 \times 105 \mathrm{mM}$ i.d.) using petroleum ether-acetone $(10: 1,9: 1,8: 1,7: 1,6: 1, v / v$, each $250 \mathrm{~mL})$ as elution system, and then further purified by using MPLC eluted with $\mathrm{MeOH}-\mathrm{H}_{2} \mathrm{O}(95: 5$, $v / v)$ to yield compound $3(2.2 \mathrm{mg})$. $\mathrm{E}_{7}(1.8 \mathrm{~g})$ and $\mathrm{E}_{8}(2 \mathrm{~g})$ were passed through a MCI gel column $\left(200 \times 40 \mathrm{mM}\right.$ i.d.) for depigmentation. The resultant methanolic eluate $(0.9 \mathrm{~g})$ of $\mathrm{E}_{7}$ was sequentially separated by MPLC eluted with a gradient of methanol in water $(75: 25,80: 20,85: 15,90: 10,100: 0, v / v$, each $70 \mathrm{~mL})$, and by Sephadex LH-20 column $(1550 \times 13.4 \mathrm{mM}$ i.d.) chromatography eluted with $\mathrm{MeOH}$, and silica gel $\mathrm{CC}$ using $\mathrm{CHCl}_{3}-\mathrm{MeOH}(98: 2, v / v)$ elution to obtain compounds 2 (4 mg) and compound $4(2.0 \mathrm{mg})$. The resultant methanolic eluate $(1.1 \mathrm{~g})$ of $\mathrm{E}_{8}$ was sequentially separated by MPLC eluted with a gradient of methanol in water (60:0, 70:30, 80:20, 90:10, 100:0, v/v, each $100 \mathrm{~mL})$ to give eight fractions $\left(\mathrm{E}_{8-1}-\mathrm{E}_{8-8}\right)$. The EtOAc-soluble fraction was subjected to silica gel $\mathrm{CC}(1000 \times 105 \mathrm{mM}$ i.d. $)$ using a gradient of $\mathrm{CHCl}_{3}-\mathrm{MeOH}(97: 3,90: 10,85: 15,70: 30,60: 40,0: 100$, $v / v$, each $3 \mathrm{~L})$ to give ten fractions $\left(\mathrm{F}_{1}-\mathrm{F}_{6}\right)$. Fraction $\mathrm{F}_{3}(6.8 \mathrm{~g})$, obtained by elution $\mathrm{CHCl}_{3}-\mathrm{MeOH}$ $(85: 15, v / v)$, was further subjected to silica gel $\mathrm{CC}(800 \times 50 \mathrm{mM}$ i.d. $)$ and successively eluted with $\mathrm{CHCl}_{3}-\mathrm{MeOH}(98: 2,95: 5,90: 10, v / v$, each $0.5 \mathrm{~L})$ to yield six sub-fractions $\left(\mathrm{F}_{5-1}-\mathrm{F}_{5-6}\right)$, Sub-fraction $\mathrm{F}_{5-3}(1.6 \mathrm{~g})$ was separated by MPLC using MeOH- $\mathrm{H}_{2} \mathrm{O}(60: 40,70: 30,80: 20,90: 10,100: 0$, v/v, each $350 \mathrm{~mL})$ at a flow rate of $10 \mathrm{~mL} / \mathrm{min}$, and further purified by Sephadex LH-20 column $(1550 \times 13.4 \mathrm{mM}$ i.d.) chromatography eluted with $\mathrm{MeOH}$ to obtain compound $6(9 \mathrm{mg})$. Fraction $\mathrm{F}_{5}(20.5 \mathrm{~g})$, obtained by elution $\mathrm{CHCl}_{3}-\mathrm{MeOH}(60: 40, v / v)$, was further subjected to silica gel $\mathrm{CC}(1000 \times 105 \mathrm{mM}$ i.d. $)$, and successively eluted with $\mathrm{CHCl}_{3}-\mathrm{MeOH}(90: 10,80: 20,70: 30,60: 40, v / v$, each 1.5 L) to obtain six sub-fractions $\left(\mathrm{F}_{5-1}-\mathrm{F}_{5-6}\right) . \mathrm{F}_{5-3}(10 \mathrm{~g})$ was separated by MPLC, and eluted with $\mathrm{MeOH}-\mathrm{H}_{2} \mathrm{O}(70: 30, v / v)$ to yield compound 1 (5 mg).

$2 \alpha, 3 \beta, 20 \alpha$-Trihydroxy-30-norolean-12-en-28-oic acid (1). White amorphous powder. $[\alpha]_{D}^{20}+106.4$ (c 0.70, MeOH). IR (KBr) $v_{\max } 3428,2939,2873,1699,1459,1380,1286,1450,1116,1047 \mathrm{~cm}^{-1}$. ESI-MS (+) $m / z: 497[\mathrm{M}+\mathrm{Na}]^{+}, 971[2 \mathrm{M}+\mathrm{Na}]^{+}$; ESI-MS (-) $m / z: 473[\mathrm{M}-\mathrm{H}]^{-}, 947$ [2M-H] $]^{-}$HR-ESIMS $m / z$ : $497.3235[\mathrm{M}+\mathrm{Na}]^{+}$(calcd for $\left.\mathrm{C}_{29} \mathrm{H}_{46} \mathrm{NaO}_{5}, 497.3237\right)$. For ${ }^{1} \mathrm{H}-\mathrm{NMR}\left(600 \mathrm{MHz}, \mathrm{C}_{5} \mathrm{D}_{5} \mathrm{~N}\right.$ ) and ${ }^{13} \mathrm{C}-\mathrm{NMR}\left(150 \mathrm{MHz}, \mathrm{C}_{5} \mathrm{D}_{5} \mathrm{~N}\right)$ data, see Table 1.

$2 \alpha, 3 \beta$-Dihydroxy-23-oxo-30-norolean-12,20(29)-dien-28-oic acid (2). White amorphous powder. $[\alpha]_{D}^{20}$ +190.0 (c 0.17, MeOH); IR (KBr) $v_{\max } 3413,2935,2861,1720,1689,1456,1384,1292,1220,1054 \mathrm{~cm}^{-1}$. 
ESI-MS (+) $m / z: 493[\mathrm{M}+\mathrm{Na}]^{+}$, ESI-MS (-) $m / z: 469[\mathrm{M}-\mathrm{H}]^{-}$. HR-ESI-MS $m / z: 493.2922[\mathrm{M}+\mathrm{Na}]^{+}$ (calcd for $\mathrm{C}_{29} \mathrm{H}_{42} \mathrm{NaO}_{5}$, 493.2924). For ${ }^{1} \mathrm{H}-\mathrm{NMR}\left(600 \mathrm{MHz}, \mathrm{C}_{5} \mathrm{D}_{5} \mathrm{~N}\right)$ and ${ }^{13} \mathrm{C}-\mathrm{NMR}\left(150 \mathrm{MHz}, \mathrm{C}_{5} \mathrm{D}_{5} \mathrm{~N}\right)$ data, see Table 1 .

\subsection{Antibacterial Assay}

The bacteriostatic activity of compounds 1-6 were monitored according to the method of Rahman with slight modifications [19]. Briefly, indicator solution $(100 \mu \mathrm{L}$, resazurin in sterile water, $100 \mu \mathrm{g} / \mathrm{mL})$ was first placed into each of the sterility control wells (11th column) on the 96 well plates, and indicator solution (about $7.5 \mathrm{~mL}, 100 \mu \mathrm{g} / \mathrm{mL})$ was mixed with test organism $\left(5 \mathrm{~mL}, 10^{6} \mathrm{cfu} / \mathrm{mL}, \mathrm{OD}_{600}=0.07\right)$ followed by transferring (100 $\mu \mathrm{L}$, each) to growth control wells (12th column) and all test wells (1-10th column). Then, each of $100 \mu \mathrm{L}$ of the test samples in beef extract peptone medium, the positive control solution were prepared by adding kanamycin sulfate and cefradine instead of the samples and the negative control solution (3\% DMSO of beef extract peptone medium) were applied to the wells in the 1st column of the plates. Once all samples and controls were properly applied to the 1 st column of wells on the plate, half of the homogenized content $(100 \mu \mathrm{L})$ from these wells was then parallel transferred to the 2nd column of wells, and each subsequent well was treated similarly (doubling dilution) up to the 10th column, followed by discarding the last $100 \mu \mathrm{L}$ aliquot. Finally, the plates were incubated at $37^{\circ} \mathrm{C}$ for $5-6 \mathrm{~h}$ until the color of growth control change to pink. The lowest concentration for each test compound at which color change occurred was recorded as the MIC value of the test compound. The Gram-(+) bacteria, Staphyloccocus aureus (CMCC26003), Bacillus cereus (CMCC63302) and Bacillus subtilis (CMCC63501), and Gram-(-) bacteria Escherichia coli (CMCC44102), Salmonella typhimurium (CMCC44102) and Shigella dysenteriae (CMCC51252) were obtained from the Guangdong Institute of Microbiology (Guangzhou, China). The multi-drug resistant Staphyloccocus aureus (MRSA) was kindly provided by Dr. Wei, X.Y. (South China Botanical Garden).

\subsection{Cytotoxic Assay}

Compounds 1-6 were evaluated for their cytotoxicity against three human cancer cell lines, human lung adenocarcinoma (A549), human cervical carcinoma (HeLa) and human liver hepatocellular carcinoma (HepG2). The three tumor cell lines were generously provided by Kunming Institute of Zoology, Chinese Academy of Sciences. The cytotoxic activities of the tested compounds were assayed according to the MTT method by using 96 well plates [20]. Briefly, the cells were cultured in RPMI-1640 medium, supplemented with 10\% fetal bovine serum in a humidified atmosphere with 5\% $\mathrm{CO}_{2}$ at $37^{\circ} \mathrm{C}$. One hundred $\mu \mathrm{L}$ of adherent cells at the density of $5 \times 10^{4}$ cell $/ \mathrm{mL}$ was seeded into each well of 96-well cell culture plates and incubated in $5 \% \mathrm{CO}_{2}$ at $37{ }^{\circ} \mathrm{C}$ for $24 \mathrm{~h}$ to form a monolayer on the flat bottoms. Then, removed the supernatant per well and subsequently added with $100 \mu \mathrm{L}$ of fresh medium and $100 \mu \mathrm{L}$ of medium containing a test compound. The plate was then incubated in $5 \% \mathrm{CO}_{2}$ at $37^{\circ} \mathrm{C}$. After $72 \mathrm{~h}, 20 \mu \mathrm{L}$ of $5 \mathrm{mg} / \mathrm{mL}$ MTT in DMSO was added into each well and incubated for $4 \mathrm{~h}$. The supernatant per well was carefully removed and $150 \mu \mathrm{L}$ of DMSO was added. The plate was then vortex shaken for $15 \mathrm{~min}$ to dissolve blue formazan crystals. The optical density (OD) of each well was measured on a Genois microplate reader (Tecan GENios, Männedorf, Switzerland) at the wavelength of 
$570 \mathrm{~nm}$. All experiments were performed in triplicate and adriamycin was used as a positive control. In each experiment, each of the tumor cell lines was exposed to the test compound at concentrations of 50, 25, $12.5,6.25,3.125,1.5625 \mu \mathrm{g} / \mathrm{mL}$. The inhibitory rate of cell growth was calculated according to the following formula: Inhibition rate $(\%)=\left(\mathrm{OD}_{\text {control }}-\mathrm{OD}_{\text {treated }}\right) / \mathrm{OD}_{\text {control }} \times 100 \%$. $\mathrm{IC}_{50}$ values were calculated by SPSS 16.0 statistic software. The values were based on three individual experiments and expressed as means \pm standard deviation (SD).

\section{6. $\alpha$-Glucosidase Inhibition Assay}

The $a$-glucosidase inhibitory activity of $1,2,5$ and $\mathbf{6}$ were determined spectrophotometrically in a 96-well microtiter plate based on $p$-nitrophenyl- $\alpha$-D-glucopyranoside (PNPG) as a substrate following the method described in the literature with slight modifications [21,22]. In brief, $\alpha$-glucosidase $(20 \mu \mathrm{L}$, $0.8 \mathrm{U} / \mathrm{mL})$ and various concentrations $(500,250,125,62.5,31.25,15.625 \mu \mathrm{g} / \mathrm{mL})$ of tested compounds $(120 \mu \mathrm{L})$ in $67 \mathrm{mM}$ phosphate buffer $(\mathrm{pH}$ 6.8) were mixed at room temperature for $10 \mathrm{~min}$. Reactions were initiated by addition of $5.0 \mathrm{mM}$ PNPG $(20 \mu \mathrm{L})$. The reaction mixture was incubated for $15 \mathrm{~min}$ at $37^{\circ} \mathrm{C}$ in a final volume of $160 \mu \mathrm{L}$. Then, $0.2 \mathrm{M} \mathrm{Na}_{2} \mathrm{CO}_{3}(80 \mu \mathrm{L})$ was added to the incubation solution to stop the reaction. The activities were detected in a 96-well plate, and the absorbance was determined at $405 \mathrm{~nm}$ (for $p$-nitrophenol). The negative blank was set by adding phosphate buffer instead of the sample via the same way as the test. Acarbose was utilized as positive control. The blank was set by adding phosphate buffer instead of the $\alpha$-glucosidase using the same method. Inhibition rate $(\%)=\left[\left(\mathrm{OD}_{\text {negative control }}-\mathrm{OD}_{\text {blank }}\right)-\left(\mathrm{OD}_{\text {test }}-\mathrm{OD}_{\text {test blank }}\right)\right] /\left(\mathrm{OD}_{\text {negative blank }}-\mathrm{OD}_{\text {blank }}\right) \times 100 \%$. $\mathrm{IC}_{50}$ values of the samples were calculated using the Microsoft Office Excel soft.

\section{Conclusions}

Two new 30-noroleanane triterpenes 1-2 were isolated from the pericarps of A. trifoliata, along with four known ones 3-6. Their structures were identified by spectroscopic means, including NMR and HRESIMS. All the compounds were isolated from the pericarps of A. trifoliata for the first time. Bioassays showed that compounds 3-6 were selectively active against four tested Gram- $(+)$ bacteria, especially 3 toward MRSA with a MIC value about five-fold stronger than the reference compound kanamycin. Compounds $\mathbf{4}$ and $\mathbf{5}$ were found to show moderate cytotoxic activity against human tumor A549 and HeLa cell lines. Compounds 1, 2, 5 and 6 were all revealed to show significant in vitro $\alpha$-glucosidase inhibitory activities which were more potent than reference compound acarbose. These findings indicate that the pericarps of $A$. trifoliata is rich in 30-noroleanane triterpenoids which are promising for exploitation as functional food ingredients or to be developed as effective and safe agents to contribute to the control and therapy of human diseases.

\section{Supplementary Materials}

Supplementary materials can be accessed at: http://www.mdpi.com/1420-3049/19/4/4301/s1. 


\section{Acknowledgments}

This research project was supported by the National Natural Science Foundation of China (30870248, 31270406, 81102351), the Innovation Program of the Chinese Academy of Sciences (KSCX2-YW-N-0804, KSCX2-EW-J-28, YG2012050 and Y39000AF03), and the Key Laboratory of Plant Resources Conservation and Sustainable Utilization, South China Botanical Garden, Chinese Academy of Sciences (No. 211027).

\section{Author Contributions}

Jing Wang performed the isolation and structure elucidation of the constituents, and participated in the bioassay experiments. Qiao-Lin Xu partially contributed the structure elucidation and together with Jing Wang prepared the manuscript. Meng-Fei Zheng collected the plant material and carried out the ethanol extraction. Hui Ren carried out the antibacterial assay. Ting Lei performed the $\alpha$-glucosidase inhibition assay. Ping $\mathrm{Wu}$ conducted the cytotoxic assay. Zhong-Yu Zhou partially contributed to the MS measurements and interpretation of those spectra. Xiao-Yi Wei provided the bacteria MRSA and contributed the optimization of the manuscript. Jian-Wen Tan planned, designed and organized the whole research of this study. All authors approved the final version manuscript.

\section{Conflicts of Interest}

The authors declare no conflict of interest.

\section{References}

1. Li, L.; Yao, X.; Zhong, C.; Chen, X.; Huang, H. Akebia: A potential new fruit crop in China. HortScience 2010, 45, 4-10.

2. Wang, Z.; Zhong, C.; Bu, F.; Peng, D.; Peng, J.; Yuan, F. Akebia - a valuable wild fruit under domestication. Agric. Sci. Technol. 2005, 6, 12-18.

3. Li, L.; Chen, X.Z.; Yao, X.H.; Tian, H.; Huang, H.W. Geographic distribution and resources status of three important Akebia species. J. Wuhan Bot. Res. 2010, 28, 497-506.

4. Jiangsu New Medical College. Dictionary of Chinese Herbal Medicines; Shanghai Science and Technology Press: Shanghai, China, 1995; p. 169.

5. Mimaki, Y.; Kuroda, M.; Yokosuka, A.; Harada, H.; Fukushima, M.; Sashida, Y. Triterpenes and triterpene saponins from the stems of Akebia trifoliata. Chem. Pharm. Bull. 2003, 51, 960-965.

6. Gao, H.M.; Wang, Z. Triterpenoid saponins and phenylethanoid glycosides from stem of Akebia trifoliata var. australis. Phytochemistry 2006, 67, 2697-2705.

7. Wang, Y.; Lu, J.; Lin, R.C. The chemical constituents from the stem of Akebia trifoliata. Chin. Tradit. Herb. Drugs 2004, 35, 495-498.

8. Guan, S.G.; Yu, W.B.; Guan, S.H. The phenolic acid and phenoglycoside of Akebia trifoliata. Lishizhen Med. Mater. Med. Res. 2010, 21, 905-906.

9. Guan, S.H.; Xia, J.M.; Lu, Z.Q.; Chen, G.T.; Jiang, B.H.; Liu, X.; Guo, D.A. Structure elucidation and NMR spectral assignments of three new lignan glycosides from Akebia trifoliata. Magn. Reson. Chem. 2008, 46, 186-190. 
10. Ma, S.C.; Cheng, D.C.; Zhao, S.J. Study on the chemical constituents of the pericarps of Akebia trifoliata var. australis. Chin. Tradit. Herb. Drugs 1993, 11, 563-566.

11. He, Y.Q.; Gao, L.M.; Wei, X.M.; Yan, H.Y. Study on the chemical constituents of fructus Akebiae. J. Northwest Norm. Univ. 2004, 40, 38-42.

12. Gao, L.M.; He, Y.Q.; Wei, X.M.; Yan, H.Y. Advance of chemical constituents and pharmacological activity of Akebia Decne. J. Northwest Norm. Univ. 2004, 40, 108-114.

13. Iwanaga, S.; Warashina, T.; Miyase, T. Triterpene saponins from the pericarps of Akebia trifoliata. Chem. Pharm. Bull. 2012, 60, 1264-1274.

14. Qu, Y.; Liang, J.; Feng, X. Research in nor-oleanane triterpenoids. Nat. Prod. Res. Dev. 2011, 23, 577-581.

15. Taniguchi, S.; Imayoshi, Y.; Kobayashi, E.; Takamatsu, Y.; Ito, H.; Hatano, T.; Sakagami, H.; Tokuda, H.; Nishino, H.; Sugita, D.; et al. Production of bioactive triterpenes by Eriobotrya japonica calli. Phytochemistry 2002, 59, 315-323.

16. Ikuta, A.; Itokawa, H. Triterpenoids of Akebia quinata callus tissue. Phytochemistry 1986, 25, 1625-1628.

17. Ikuta, A.; Itokawa, H. A triterpene from Akebia quinata callus tissue. Phytochemistry 1988, 27, 3809-3810.

18. Ieyama, T.; Gunawan-Puteri, M.D.; Kawabata, J. $\alpha$-Glucosidase inhibitors from the bulb of Eleutherine americana. Food Chem. 2011, 128, 308-311.

19. Rahman, M.M.; Gray, A.I. A benzoisofuranone derivative and carbazole alkaloids from Murraya koenigii and their antimicrobial activity. Phytochemistry 2005, 66, 1601-1606.

20. Xu, X.Y.; Xie, H.H.; Hao, J.; Jiang, Y.M.; Wei, X.Y. Eudesmane sesquiterpene glucosides from lychee seed and their cytotoxic activity. Food Chem. 2010, 123, 1123-1126.

21. Feng, J.; Yang, X.W.; Wang, R.F. Bio-assay guided isolation and identification of $\alpha$-glucosidase inhibitors from the leaves of Aquilaria sinensis. Phytochemistry 2011, 72, 242-247.

22. Li, W.; Fu, H.W.; Bai, H.; Sasaki, T.; Kato, H.; Koike, K. Triterpenoid Saponins from Rubus ellipticus var. obcordatus. J. Nat. Prod. 2009, 72, 1755-1760.

Sample Availability: Please contact the corresponding author.

(C) 2014 by the authors; licensee MDPI, Basel, Switzerland. This article is an open access article distributed under the terms and conditions of the Creative Commons Attribution license (http://creativecommons.org/licenses/by/3.0/). 